Bangladesh J. Plant Taxon. 28(2): 385-393, 2021 (December)

(C) 2021 Bangladesh Association of Plant Taxonomists

DOI: https://doi.org/10.3329/bjpt.v28i2.57134

\title{
SEED MACRO- AND MICRO-MORPHOLOGY OF SOME SPECIES OF KICKXIA DUMORT, SCROPHULARIA L. AND PLANTAGO L. FROM SAUDI ARABIA
}

\author{
Luluah M. Al Masoudi*, Najat A. Bukhari ${ }^{2}$ and Mona Al Whibi ${ }^{2}$ \\ Department of Biology, Faculty of Science, Taif University, Taif, Saudi Arabia
}

Keywords: Seed morphology; SEM study; Kickxia; Scrophularia; Plantago; Saudi Arabia.

\begin{abstract}
The seed macro- and micro-morphological characters of 13 species belonging to three genera; Kickxia Dumort, Scrophularia L. and Plantago L., collected from different localities of Saudi Arabia, were studied using a Stereomicroscope and Scanning Electron Microscope for evaluating their taxonomic relationships. Three macro-morphological characters of seeds were shape, size, and color while three diagnostic micromorphological characters were seed coat sculpture, the anticlinal and periclinal wall., The seed shape seems to be specific in Plantago L. (peltate, angled) than the two other genera while the color and seed size show little importance. The Plantago L. has a specific rugose sculpture while the other two genera have either tuberculate or alveolate. So Plantago L. was possessed no affinities to Kickxia Dumor or Scrophularia L.. This observation gives extra support to the earlier taxonomic views that suggested the retention of two genera in the traditional family Scrophulariaceae and maintaining Plantago L. in a separate monogeneric family Plantaginaceae Detailed analysis of seed characters of more species is needed to clarify the systematic relationships between the three genera. A key to the identification of studied species based on seed micro- and macro-morphological characters is provide.
\end{abstract}

\section{Introduction}

Scrophulariaceae is a large worldwide family (Miranda, 1988), with approximately 222 genera and 4480 species (Willis, 1973), mostly found in temperate zones of the northern hemisphere (Heywood, 1985).

The Kickxia Dumort (Scrophulariaceae) is one of the most important genera, with roughly 47 species (Mabberley, 1997). The genus is represented in Saudi Arabia by 10 species (Chaudhary, 2001), the majority of which are found in the south and west of the country. Scrophularia L. (Scrophulariaceae) is another major genus with over 300 species represented in both the ancient and modern worlds (Lersten and Curtis, 1997). It is represented by four species in Saudi Arabia (Chaudhary, 2001). Since ancient times, many species of this genus have been utilized as traditional medicine. The Plantaginaceae is a worldwide family of three genera: Plantago, Littorella, and Bougueria, which grow in a variety of environments (Bentham, 1846; Wettstein, 1891; Dahlgren, 1975; Cronquist, 1981; Heywood, 1993; Takhtajan, 1997).

Plantago L. (Plantaginaceae) is a perennial herb with a rosette of leaves at the base of the plant (Chiang et al., 2002). The herb can be used to treat a variety of ailments. It is used to treat hypercholesterolemia and lower blood sugar levels (Haddadian et al., 2014). It is also used to treat cancer (Souri et al., 2008; Pourmorad et al., 2006).It is represented by at least 12 species in Saudi

*Corresponding author, Email: lm.al-masoudi@tu.edu.sa

${ }^{2}$ Department of Botany and Microbiology, Faculty of Science, King Saud University, Riyadh, Saudi Arabia. Email: najatab@ksu.edu.sa; malwhibi@ksu.edu.sa 
Arabia (Chaudhary, 2001). Plantaginaceae and Scrophulariaceae have a tight link, according to several scientists (Takhtajan, 1980; Heywood, 1993; Mabberley, 1997). The notion of Plantaginaceae was broadened in Judd et al. (1999) and APG (2009) classifications to cover numerous taxa that were previously classified to the Scrophulariaceae based on molecular criteria. The existence of certain closely related families, such as Plantaginaceae, Orobanchaceae, and Acanthaceae, may further make the bounds of the Scrophulariaceae problematic.

The links between the traditional Plantaginaceae family and other families are still murky and need to be clarified (Heywood, 1993; Albach et al., 2004). The purpose of this study is to describe the seed morphological features in details to assess their utility in understanding the relationships among the three taxa analyzed (Kickxia, Scrophularia and Plantago). The findings are reviewed in considering the various classification systems.

\section{Materials and Methods}

The seeds of 12 species from two genera, Kickxia and Scrophularia of the family Scrophulariaceae and one species from Plantago of the Plantaginaceae were studied. The fresh seeds were collected from different localities of the Saudi Arabia as well as from preserved Specimens available at the Herbarium of Collage of Science, King Saud University (Table 1). The study was conducted at the Central Laboratory of Science and Medicine Department, King Saud University.

Table 1. List of studied species and their collected locations.

\begin{tabular}{|c|c|c|}
\hline $\mathrm{S} / \mathrm{N}$ & Name of Species & Localities \\
\hline 1 & Kickxia abhaica D. A. Sutton & Wadi Alus, Rejal Almaa, Abha \\
\hline 2 & K. acerbiana (Boiss.) Tackh. \& Boulos & Yanbu-Omlog Road \\
\hline 3 & K. aegyptiaca (L.) Nab. & Al sheheia, Alqassim \\
\hline 4 & K. corallicola D. A. Sutton & Farasan Island, Jizan \\
\hline 5 & K. elatine (L.) Dumort. & $\begin{array}{l}\text { Herbarium of Ministry of Environment, Water \& } \\
\text { Agriculture }\end{array}$ \\
\hline 6 & K. hastata (R. Br. Ex. Benth.) Dandy & $\begin{array}{l}\text { Herbarium of Ministry of Environment Water, \& } \\
\text { Agriculture }\end{array}$ \\
\hline 7 & K. petiolate D. A Sutton & $\begin{array}{l}\text { Herbarium of Botany \& Microbiology Department, } \\
\text { Collage of Science, King Saud University }\end{array}$ \\
\hline 8 & $\begin{array}{l}\text { K. pseudoscoparia v. w. Smith \& D. A. } \\
\text { Sutton }\end{array}$ & Al sail Alsageer, Taif \\
\hline 9 & K. scalarum D. A. Sutton & $\begin{array}{l}\text { Herbarium of Ministry of Environment water \& } \\
\text { Agriculture }\end{array}$ \\
\hline 10 & K. spartioides (Brouss. ex. Bush Janch.) & $\begin{array}{l}\text { Herbarium of Botany \& Microbiology Department, } \\
\text { Collage of Science, King Saud University }\end{array}$ \\
\hline 11 & Plantago major L. & Wadi Darak - Al Mandaq \\
\hline 12 & Scrophularia deserti Del. & Bani Saad, Taif-Albaha Road \\
\hline 13 & S. peyronii Post & $\begin{array}{l}\text { Hebarium of Ministry of Environment. water \& } \\
\text { Agriculture }\end{array}$ \\
\hline
\end{tabular}

The external macro-morphological characters of the mature seeds were investigated with the aid of a Stereomicroscope. For seed size and width, the mean value of three seeds of each species were measured by a Micrometer. 
For Scanning Electron Microscopic (SEM) examinations, mature dried seeds were selected, mounted on stubs using double side adhesive tape, coated in auto fine coater (JFC-1600) with gold by a Zeiss Scanning Electron Microscope, model (JEOL-JSM-6060 LV) at the electron microscope unite in the Central Laboratory of Science and Medicine Department, King Saud University. These were then examined and photographed with an accelerating voltage $15 \mathrm{KV}$. Terminology of seed coat sculpturing basically following Stearn (1992) and Juan et al. (1997, 2000).

For numerical analysis we used the NTSYS-pc 2.2. software package according to the method of Rohlf, (2009) and then generated a cluster analysis of the similarity and dissimilarity matrix between the species under study to construct a Dendrogram.

\section{Results and Discussion}

The macro-morphological characters of the studied species presented in Table 2 revealed that the Seed Shape was varied from reniform in Kickxia abhaica, K. scalarum and K. spartioides, prismatic cylindrical in $K$. aegyptiaca, ovate in K. elatine, oblong ovate in the two Scrophularia species, peltate angled with rounded apical scar in Plantago major, rounded in Kickxia petiolate while ellipsoide in the remaining four species. The Seed Size ranges from large seeds (more than $500 \mu \mathrm{m}$ long) in Kickxia acerbiana $(866 \times 591.6 \mu \mathrm{m})$ to small (Less than $500 \mu \mathrm{m}$ ) in $K$. spartioides $(367.08 \times 243.0 \mu \mathrm{m})$, K. petiolata $(367.3 \times 282.1 \mu \mathrm{m})$ followed by $K$. hastata $(367.7$ $\mathrm{x} 234.5 \mu \mathrm{m})$. The rest of the studied species possessed medium sized seeds $(414-571 \mu \mathrm{m})$ long. The seed color showed low variation from brown in Kickxia acerbiana, $K$. elatine and $K$. spartioides to dark brown in the remaining studied species.

Table 2. The macro-morphological seed characters of the studied species.

\begin{tabular}{lllcl}
\hline S/N & Taxa & Seed shape & $\begin{array}{c}\text { Size } \\
\text { length x width }\end{array}$ & color \\
\hline 1 & Kickxia abhaica & Reniform & $571.7 \times 358.1$ & Dark brown \\
2 & K. acerbiana, & Ellipsoid & $866.0 \times 591.6$ & Brown \\
3 & K. aegyptiaca & Prismatic/cylindrical & $447.5 \times 304.5$ & Dark brown \\
4 & K. corallicola & Ellipsoid & $440.4 \times 283.8$ & Brown \\
5 & K. elatine & Ovate & $532.1 \times 380.1$ & Brown \\
6 & K. hastata & Ellipsoid & $367.7 \times 234.5$ & Dark brown \\
7 & K. petiolate & Rounded & $367.3 \times 282.1$ & Dark brown \\
8 & K. pseudoscoparia & Ellipsoid & $558.3 \times 381.9$ & Dark brown \\
9 & K. scalarum & Reniform & $416.1 \times 336.8$ & Dark brown \\
10 & K. spartioides & Reniform & $367.1 \times 243.0$ & Brown \\
11 & Plantago major & Peltate angled with & $414.6 \times 289.1$ & Dark brown \\
& & apical rounded scar & & \\
12 & Scrophularia deserti & Oblong ovate & $490.2 \times 289.9$ & Brown \\
13 & S. peyronii & Oblong ovate & $504.9 \times 402.5$ & Dark brown \\
\hline
\end{tabular}

The results also revealed that the variations of seed shape and size are of great importance in taxa delimitation while seed color of little importance. Also, the seed shape of Plantago major (peltate/angled with apical rounded scar) diagnostic and clearly separated it than the other two genera. 
Esau (1977), Barthlott (1984), Werker (1997), Abdel Khalik and Maesen (2002), Akbari and Azizan (2006), Abdel Khalik (2010), Kaya et al. (2011), Abdel Khalik and Hassan (2012), Bona (2013), Ghimire et al. (2017) stated that, the seed morphology and anatomical characters are of taxonomic importance at both sub generic and sub familial levels.

The micro-morphological characters investigated by SEM of the studied species presented in Table 3 and Figs 1-13 revealed that the Shape of the epidermal cells are penta-hexa-polygonal except in Kickxia corallicola which is ill-defied, while it is irregular in Plantago major.

Table 3. Micro-morphological seed characters of the studied species.

\begin{tabular}{|c|c|c|c|c|c|}
\hline $\mathrm{S} / \mathrm{N}$ & Taxa & Cell shape & $\begin{array}{l}\text { Anticlinal } \\
\text { wall }\end{array}$ & $\begin{array}{l}\text { Periclinal } \\
\text { wall }\end{array}$ & Seed coat sculpture \\
\hline 1 & Kickxia abhaica & Pentagonal & Channeled & $\begin{array}{l}\text { Raised with } \\
\text { acute apex }\end{array}$ & $\begin{array}{l}\text { Tuberculate/cristate (tubercles } \\
\text { with obtuse conical apex). }\end{array}$ \\
\hline 2 & K. acerbiana, & Pentagonal & Channeled & $\begin{array}{l}\text { Raised with } \\
\text { obtuse apex }\end{array}$ & Tuberculate with obtuse apex. \\
\hline 3 & K. aegyptiaca & Polygonal & Levelled & $\begin{array}{l}\text { Raised with } \\
\text { broad apex }\end{array}$ & $\begin{array}{l}\text { Tuberculate/ verrucose with } \\
\text { broad base and globes cells }\end{array}$ \\
\hline 4 & K. corallicola & ill-defined & Levelled & $\begin{array}{l}\text { Raised with } \\
\text { broad apex }\end{array}$ & $\begin{array}{l}\text { Tuberculate /verrucose with } \\
\text { broad base and globes cells }\end{array}$ \\
\hline 5 & K. elatine & Hexagonal & $\begin{array}{l}\text { Raised/Un } \\
\text { dulate }\end{array}$ & Concave & Reticulate/ ridged or undulate \\
\hline 6 & K. hastata & Pentagonal & Levelled & $\begin{array}{l}\text { Raised with } \\
\text { obtuse apex }\end{array}$ & Tuberculate with obtuse apex. \\
\hline 7 & K. petiolate & Pentagonal & Levelled & $\begin{array}{l}\text { Raised with } \\
\text { obtuse apex }\end{array}$ & Tuberculate tubercles conical \\
\hline 8 & K. pseudoscoparia & Pentagonal & Levelled & $\begin{array}{l}\text { Raised with } \\
\text { acute apex }\end{array}$ & Tuberculate tubercles papillate \\
\hline 9 & K. scalarum & Pentagonal & $\begin{array}{l}\text { Levelled/ } \\
\text { undulate }\end{array}$ & $\begin{array}{l}\text { Raised with } \\
\text { acute apex }\end{array}$ & $\begin{array}{l}\text { Tuberculate tubercles conical, } \\
\text { long }\end{array}$ \\
\hline 10 & K. spartioides & Pentagonal & Levelled & $\begin{array}{l}\text { Raised with } \\
\text { acute apex }\end{array}$ & $\begin{array}{l}\text { Tuberculate tubercles conical, } \\
\text { long }\end{array}$ \\
\hline 11 & Plantago major & Irregular & $\begin{array}{l}\text { Slightly / } \\
\text { Raised }\end{array}$ & $\begin{array}{l}\text { Concave/ } \\
\text { Striated }\end{array}$ & Rugose/reticulate \\
\hline 12 & $\begin{array}{l}\text { Scrophularia } \\
\text { deserti }\end{array}$ & Hexagonal & $\begin{array}{l}\text { Raised } \\
\text { with wax }\end{array}$ & Flat/Ribbed & Alveolate-vesicles absent \\
\hline 13 & S. peyronii & $\begin{array}{l}\text { Penta- } \\
\text { Hexagonal }\end{array}$ & $\begin{array}{l}\text { Raised } \\
\text { with wax }\end{array}$ & Flat/Ribbed & Alveolate-vesicles present \\
\hline
\end{tabular}

Anticlinal wall boundaries: These boundaries are well developed and indicated by channels in Kickxia abhaica and $K$. acerbiana, raised without wax in K. elatine and Plantago major, raised with wax in the two Scrophularia species, levelled in the remaining studied species.

Periclinal cell wall: Are flat ribbed in the two Scrophularia species, concave striated in Plantago major, concave without stria in Kickxia elatine while raised in the remaining studied species. It was raised with obtuse apex in $K$. acerbiana, $K$. hastata and $K$. petiolate, raised with acute apex in $K$. abhaica, $K$. pseudoscoparia, $K$. scalarum and $K$. spartioides while raised with broad base and globose cells in $K$. aegyptiaca and $K$. corallicola. 

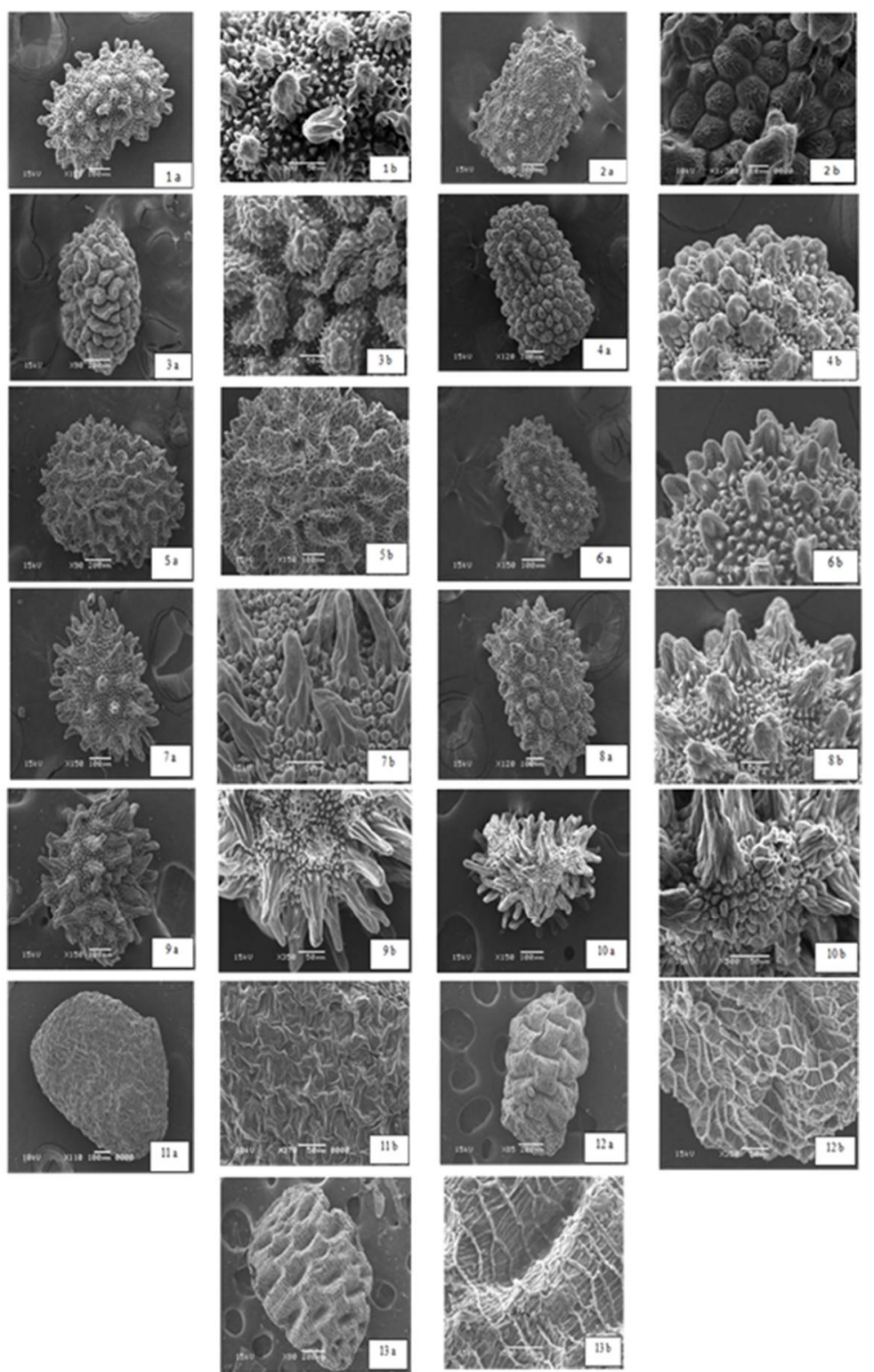

Figs. 1-13. SEM seed characters of studied species:1 a, b. Kickxia abhaica; 2 a, b. K. acerbiana; 3 a, b. K. aegyptiaca; 4 a, b K. corallicola; 5 a, b K. elatine; 6 a, b K. hastata; 7a, b K. petiolate; 8 a, b. K. pseudoscoparia; 9 a, b. K. scalarum; 10 a, b. K. spartioides; 11 a, b. Plantago major; 12 a, b. Scrophularia deserti; 13 a, b. S. peyronii. a-general seed shape, b- seed coat surface.

Seed coat sculpture: Scanning electron microscope (SEM) has been providing detailed and useful data on the fine structure of the seed coat in various genera of Scrophulariaceae (Canne, 1979, 1980; Elisens and Tomb, 1983; Sutton, 1988). Also, according to Molau (1990) the morphology of the seed coat provides a major diagnostic and significant features at tribes and subtribes of Scrophulariaceae. 
All the studied Kickxia species except $K$. elatine, show tuberculate/ cristate seed coat sculpture with different tubercles or crista. The tubercles either small with obtuse apex or with broad base and globose cells or short papillated or long conical in shape.

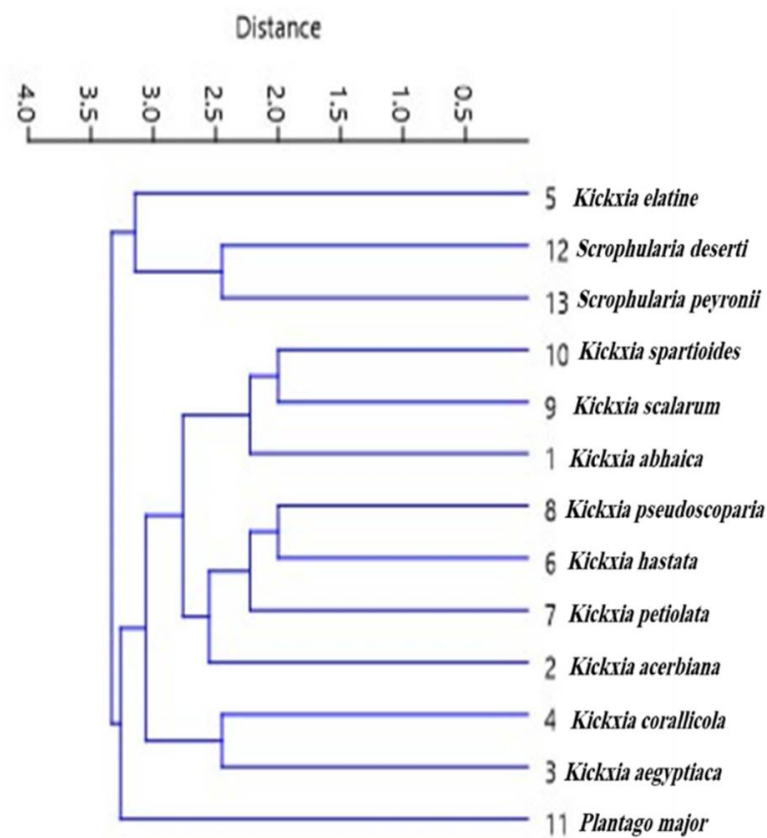

Fig. 14. Evolutionary Relationship Tree of 13 species based on seed phenotypes.

The presence of seed surface with developed protuberances seems to have adaptive advantages for these seeds. Barthlott (1981) stated that such seeds with tubercles are much less to be contaminated by pathogens than smooth ones. Also, the rough surface could help to control the temperature in sunlight and have hydration ability which could create microclimate for the seeds to avoid drying damage as indicated by Hedge (1970).

With respect to Plantagomajor and Kickxiaelatine, the seed coat characterized by rugosereticulate sculpture. This result in accordance with Shehata and Loutfy (2006) with respect to Plantago. Pijl (1982) stated that, reticulate seed coat has often been related to water dispersion due to that these seeds having the ability to trap air, thus can float easily.

The results were cleared that, the seed coat sculpture could be useful in separation between the three studied genera. This in accordance with Attar et al. (2007) who stated that seed surface ornamentation can used for species delimitation in Verbascum (Scrophulariaceae).

The results cleared that; the seed coat sculpture as shown in the SEM micrographs varied in their appearance among the three studied genera. Only, the two Scrophularia species have seed coat with alveolate-reticulate Sculpture, the alveoli arranged in longitudinal rows with vesicles in S. peyronii and without vesicles in S. deserti. This result in agreement with Sutton (1988).

In conclusion, this study revealed that, some seed morphological characters are presented as a taxonomic criterion for genera delimitation. It was separated Plantago major than the two other studied genera based on seed shape and seed coat sculpture. Also, the dendrogram (Fig. 14) showed clearly that Plantago major was separated in independent cluster away from the rest of the 
studied species through significant characters; seed shape, epidermis, cell shape, periclinal and anticlinal walls as well as seed sculpture. While $K$. elatine combined with the two Scrophularia species in one cluster. The results in accordance with Hamed et al. (2014) and confirms the earlier views of some authors (Wettstein, 1895) and others for maintaining Plantago as a separate monogeneric family (Plantaginaceae) while grouping the other two genera Kickxia and Scrophularia in family Scrophulariaceae. However, this result contradicts with Albach et al. (2005) finding, who grouped Kickxia in tribe: Antirrhineae while Plantago in tribe: Plantagineae under new circumscribed family Plantaginaceae.

Despite the progression in the molecular and phylogenetic studies that has been made toward a new circumscription of Plantaginaceae and Scrophulariaceae, several important problems remain obscured and unsolved. For more accurate assignment of some genera of the two families, more studies on many species are still needed.

Based on these macro- and micro-morphological characters of seeds, an identification key to the studied species is prepared as follows.

\section{Key to the species}

+ Seed length long $(866 \mu \mathrm{m})$, seed shape ellipsoid

Kickxia acerbiana

++ Seed length short $(367 \mu \mathrm{m})$

- Seed shape ellipsoid

K. hastata

- - Seed shape rounded

K. petiolata

- - Seed shape reniform

K. spartioides

+++ Seed length moderate size $(414-571 \mu \mathrm{m})$

1. Seed shape prismatic/ cylindrical

2. Seed shape peltate, angled with apical rounded scar

K. aegyptiaca

3. Seed shape ovate

Plantago major

4. Seed shape oblong ovate

a. Seed coat sculpture alveolate with vesicles

$K$. elatine

b. Seed coat sculpture alveolate without vesicles

Scrophularia peyronii

S. deserti

5. Seed shape reniform

- Anticlinal cell wall channel, seed coat sculpture with obtuse apex

- - Anticlinal cell wall levelled, undulate, seed coat

K. abhaica sculpture with long conical tubercles

K. scalarum

6. Seed shape ellipsoid

- Seed sculpture tubercles with broad base and globose

K. corallicola cells

- Seed sculpture with papillate tubercles

K. pseudoscoparia

\section{Conclusion and Recommendation}

The Morphological characteristics of the seed surface are important in defining, separating, and studying the evolutionary relationships between Taxa. This observation gives extra support to the taxonomic views that suggest the retention of the Kickxia in the family of Scrophulariaceae s.l. and maintaining Plantago in a separate monogenetic family of Plantaginaceae using a stereo and scanning electron microscope. 


\section{References}

Abdel Khalik, K. and Maesen, L. 2002. Seed morphology of some tribes of Brassicaceae (implications for taxonomy and species identification for the flora of Egypt). Blumea 47(2): 363-383.

Abdel Khalik, K. 2010. Seed coat morphology its systematic significance in Juncus L. (Juncaceae) in Egypt. J. syst and Evol. 48: 215-223. https://doi.org/10.1111/j.1759-6831.2010.00075.x

Abdel Khalik, K. and Hassan, N. 2012. Seed coat trichome micromorphology of Egyptian Fagonia (Zygophyllaceae) with emphasis on its systematic implication. Nordic J. Bot. 30: 116-126. https://doi. org/10.1111/j.1756-1051.2011.01112.x

Attar, F., Keshvari, A., Ghahreman, A. and Zarre, S. 2007. Micromorphological studies on Verbascum (Scrophulariaceae) in Iran with emphasis on surface, capsule ornamentation and trichomes. Flora 202: 169-175. https://doi.org/10.1016/j.flora.2006.04.001

Akbari, R. and Azizan, D. 2006. Seed morphology and seed coat Sculpturing of Epilobium L. species (Onagraceae Juss.) from Iran. Turk. J. Bot. 30: 435-440.

Albach, D., Martine, M., Fischer, M. and Chase, M. 2004. A new classification of the tribe Veronicaceae, problems and a possible solution. Taxon 53(2):429-452.

Albach, D., Meudt, H. and Oxelman, B. 2005. Piecing together the "New Plantaginaceae". Am. J. Bot. 92(2): 297-315. https://doi.org/10.3732/ajb.92.2.297

APG (Angiosperm Phylogeny Group) 2009. An Update of the Angiosperm Phylogeny Group classification for orders and families of flowering plants. The Linnean Society of London. Bot. J. Linn. Soc. 141: 105121. https://doi.org/10.1111/j.1095-8339.2009.00996.x

Barthlott, W. 1981. Epidermal and seed surface characters of plants: systematic applicability and some evolutionary aspects. Nord. J. Bot. 1: 345-355. https://doi.org/10.1111/j.1756-1051.1981.tb00704.x

Barthlott, W.1984. Microstructural Features of Seed Surface. In: Heywood, V.H. and Moore, D.C., Eds., Current Concepts in Plant Taxonomy, Academic Press, Cambridge, pp. 95-105.

Bentham, G. 1846. Scrophulariaceae. In: A., de candolle (ed.), prodromus systematis naturalis regni vegetabitis, victor Masson, Paris, France.

Bona, M. 2013. Seed micro sculpturing of Turkish Lepidium (Brassicaceae) and its systematic application Turk. J. Bot. 37: 662-668. https://doi.org/10.3906/bot-1207-2

Canne, J. 1979. A light and scanning electron microscope study of seed morphology in Agalinis (Scrophulariaceae) and its taxonomic significance. Syst. Bot. 4: 281-296. https://doi.org/10. 2307/2418806

Canne, J. 1980. Seed surface features in Aureolaria, Brachystigma, Tomanthera and certain South American Agalinis (Scrophulariaceae). Syst. Bot. 5: 241-252. https://doi.org/10.2307/2418371

Chaudhary, S.A. 2001. The Flora of the Kingdom of Saudi Arabia. Ministry of Agriculture, Riyadh.

Chiang, L., Chiang, W., Chang, M., Ng, L. and Lin, C. 2002. Antiviral activity of Plantagomajor extracts and related compounds in vitro. Antiviral Res. 55(1): 53-62. https://doi.org/10.1016/S0166-3542 (02)00007-4

Cronquist, A. 1981. An Integrated System of Classification of Flowering Plants. New York. Columbia University Press.

Dahlgren, R. 1975. A system of classification of the angiosperms to be used to demonstrate the distribution on of characters. Bot. Not. 128: 119-147.

Elisens, N. and Tomb, A. 1983. Seed morphology in New World Antirrhineae (Scrophulariaceae): systematic and phylogenetic implications. Plant syst. Evol. 142: 23-4. https://www.jstor.org/stable/23642747

Esau, K. 1977. Anatomy of the seed plants. $2^{\text {nd }}$ edition, John Wiley and Sons Ltd, New York.

Ghimire, B., Choi, G., Lee, H., Heo, K. and Jeong, M. 2017. Morphological studies on seeds of Scrophulariaceae s.l. and their systematic significance. Advances in seed Biology. https://doi.org/ 10.5772/intechopen.70572

Haddadian, K., Haddadian, K. and Zahmatkash, M. 2014. A review of Plantago plant. Ind. J. Trad. Knowl. 13(4): 681-685. http://hdl.handle.net/123456789/29518 
Hamed, K., Hassan, S., Mohamed, A. and Hosney, N. 2014. Morphological and anatomical study on Plantaginaceae Juss. and some related taxa of Scrophulariaceae Juss. Egypt. J. Exp. Biol. (Bot.) 10(2): 135-146.

Hedge, V.H. 1970. Observatios on the mucilage of Salvia fruits. Notes from the Royal Botanic Garden, Edinburgh 30: 79-95.

Heywood, V. 1985. Las Planta conores: Barcelona Reverte A.

Heywood, V. 1993. Flowering Plants of the World. Oxford: Andromeda, Ltd.

Juan, R., Fernandez, I. and Pastor, J. 1997. Systematic consideration of fruits and seeds in the genus Verbascum (Scrophulariaceae). Ann. Bot. 80: 591-598.

Juan, R., Pastor, J. and Fernaandez, I. 2000. SEM and light microscope observations on fruit and seeds in Scrophulariaceae from Southwest Spain and their systematic significance. Annals of Bot. 86(2): 323 338. https://doi.org/10.1006/anbo.2000.1188

Judd, W., Campbell, C., Kellogg, E., Stevens, P. and Donoghue, M. 1999. Plant Systematics: A phylogenetic Approach. Fourth Edition, Sinauer Associates is an imprint of Oxford University Press.

Kaya, M., Ünal, F., Özgökçe, B., Dogan, B. and Doğan, E. 2011. A Fruit and seed morphology of six species previously placed in Malcolmia (Brassicaceae) in Turkey and their taxonomic value. Turk. J. Bot 35: 653-662https://doi.org/10.3906/bot-1010-99

Lersten, N. and Curtis, J. 1997. Anatomy and distribution of foliar idioblasts in Scrophularia and Verbascum (Scrophulariaceae). Amr. J. Bot. 84: 1638-1645.https://doi.org/10.2307/2446461

Mabberley, D. 1997. The Plant Book, A Portable Dictionary of the Vascular Plants, 2nd edn. Cambridge University Press, Cambridge. https://doi.org/10.1002/fedr.19981090507

Miranda, G. 1988. Genera of Scrophulariaceae in the paramose of the venezuclan Andes. Brittonia 40(2): 235-239.

Molau, V. 1990. The genus Bartsia (Scrophulariaceae- Rhinanthoidea). Opera Botanica 102: 1-99.

Pijl, L. 1982. Principles of dispersal in higher plants. Berlin: Springer-Verlag.

Pourmorad, F., Hosseinimehr, S. and Shahabimajd, N. 2006. Antioxidant activity, phenol, and flavonoid contents of some selected Iranian medicinal plants. Afr. J. Biotechnol. 5(11): 1142-1145.

Rohlf, F. J. 2009. NTSYS-PC, Numerical Taxonomy and Multivariate AnalysisSystem. Version 2.2 Exeter software. Applied Biostatistics Inc. New York.

Shehata, A. and Loutfy, H. 2006. On the taxonomy of Plantaginaceae Juss. Sensu lato: evidence from SEM of the seed coat. Turk. J. Bot. 30: 71-84.

Souri, E., Amin, G., Farsam, H. and Barazandeh, M. 2008. Screening of antioxidant activity and phenolic content of 24 medicinal plant extracts. Daru. 16(2): 83-87.

Stearn, W. 1992. Botanical Latin. 4th edition, David and Charles, Newton Abbot, Devon, London pp. 546.

Sutton, D. 1988. A Revision of the tribe Antirrhineae (Scrophulariaceae) Oxford University Press, Oxford.

Takhtajan, A. 1997. Diversity and classification of flowering plants. Columbia University press, New York, USA.

Takhtajan, A. 1980. Outline of the classification of flowering plants. Bot. Rev. 46: 226-359. https://www.jstor.org/stable/4353970

Wettstein, R. 1891. Scrophulariaceae. In: "Die Naturlichen pflanzen familien, (Engler A, Prantl K. Eds). Wilhlelm Engelman, Leipzig, Germany 4(3b): 39-107.

Wettstein, R. 1895. Scrophulariaceae in Engler and Prantl. (Ed). Die Naturalichen pflanzenfamilien (14). Leipzig Wihelm Engelman.

Werker, E. 1997. Seed Anatomy: Handbook of Botany 10, part 3. Berlin: Borntrager press.

Willis, J. 1973. A Dictionary of the Flowering Plants and Ferns. University Press. Cambridge. 